\title{
DP. 2537
}

Y-2173

AN EVALUATION OF TWO STYLES OF SLOTTED, FLAT-HEAD SCREWS

C. A. Reeves, Jr

W. B. Johnson

April 1979

UNION CARBIDE

\section{OAK RIDGE Y-12 PLANT} OAK RIDGE. TENNESSEE

prepared for the U.S. DEPARTMENT OF ENERGY under

U.S. GOVERNMENT Contract W-7405 eng 26 


\section{DISCLAIMER}

This report was prepared as an account of work sponsored by an agency of the United States Government. Neither the United States Government nor any agency Thereof, nor any of their employees, makes any warranty, express or implied, or assumes any legal liability or responsibility for the accuracy, completeness, or usefulness of any information, apparatus, product, or process disclosed, or represents that its use would not infringe privately owned rights. Reference herein to any specific commercial product, process, or service by trade name, trademark, manufacturer, or otherwise does not necessarily constitute or imply its endorsement, recommendation, or favoring by the United States Government or any agency thereof. The views and opinions of authors expressed herein do not necessarily state or reflect those of the United States Government or any agency thereof. 


\section{DISCLAIMER}

Portions of this document may be illegible in electronic image products. Images are produced from the best available original document. 
Printed in the United States of America. Available from National Technical Information Service

U.S. Department of Commerce

5285 Port Royal Road, Springfield, Virginia 22161

Price: Printed Copy $\$ 4.00$; Microfiche $\$ 3.00$

This report was prepared as an account of work sponsored by an agency of the United States Government. Neither the United States Government nor any agency thereof, nor any of their employees, nor any of their contractors, subcontractors, or their employees, makes any warranty, express or implied, nor assumes any legal liability or responsibility for any third party's use or the results of such use of any information, apparatus, product or process disclosed in this report, nor represents that its use by such third party would not infringe privately owned rights. 
Date of Issue: April 30, 1979

$Y \cdot 2 \cdot 173$

Distribution Category: UC-38

\section{AN EVALUATION OF TWO STYLES OF SLOTTED, FLAT-HEAD SCREWS}

C. A. Reeves, Jr

W. B. Johnson

Physical Testing Department

Y-12 Product Certification Division

This report was prepared as an account of work shonsored by the United States Govemment. Neither the United States nor the United States Department of

Eneras any of their employees, nor any of theis Enetg. nors ancontractors, or their employees, makes contractors, subconess or implied, or assumes any legal ling accuracy, completeness liability or respony information, apparatus, product or or usefulness of dny teresents that its use would not

infringe privately owned rights. 


\section{ABSTRACT}

A series of torque tests were performed to evaluate the relative merits of two different flat-head screws fabricated from a uranium-6\% niobium alloy. The screws tested were machined with both normal, straight-through slots in the head and with slots having radiused bottoms. Test results indicate that both designs easily surpass the required 20-inch-pound-proof torque. 
CONTENTS

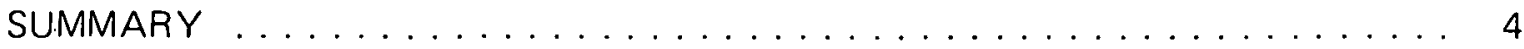

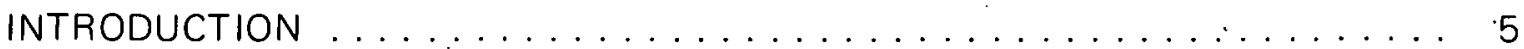

EVALUATION OF FLAT-HEAD SCREWS $\ldots \ldots \ldots \ldots \ldots \ldots$

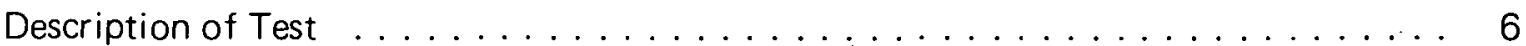

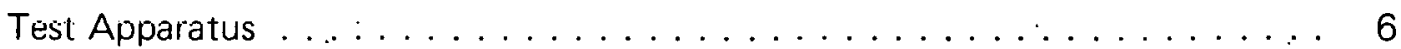

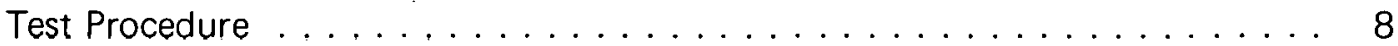

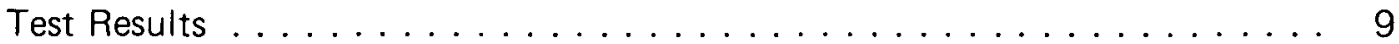

Conclusions and Recommendations . . . . . . . . . . . . . . . . . 10

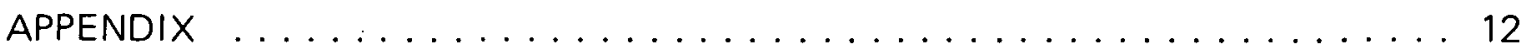

Applicable Drawings . . . . . . . . . . . . . . . . . . . . . . . . . . . 12

Notes for the Screw Drawings . . . . . . . . . . . . . . . . . . . 12 


\section{SUMMARY}

A series of tests were performed on flat-head machine screws in order to evaluate two different head-slot designs. The screws were fabricated from uranium-6\% niobium (U-6 Nb) alloy in order to simulate actual in-service usage. The two slot designs were: (1) a normal, straight-through slot, and (2) a radiused-bottom slot with a configuration similar in appearance to a Woodruff key.

Tests were performed on an existing small torque test fixture with special adapters fabricated for these tests. Two different styles of screwdriver blades were investigated for both slot designs.

Test results indicate that either slot design is more than adequate to meet the 20 -inch-pound-proof torque requirement. Failure in the normal slotted screws occurred with a tensile failure of the screw itself at the base of the head. Maximum torque was reached for some of the other screws when the screwdriver backed out of the slot. This action occurred at a torque somewhat lower than the failure torque for the normal slotted screws. The remainder of these screws failed in the same manner as did the normal slotted screws. 


\section{INTRODUCTION}

These tests were performed at the request of the Fabrication Division of the Oak Ridge Y-12 Plant(a) in order to evaluate two proposed alternatives to a Phillips-head-style screw proposed for usage in a future assembly to be fabricated. The tests were deemed to be necessary, due to the high projected costs to machine the requested screw head. Due to the low installation torque (12 inch pounds) required in the assembly, it was concluded that other head styles, less costly to machine, would be adequate for this assembly.

(a) Operated by the Union Carbide Corporation's Nuclear Division for the Department of Energy. 


\section{EVALUATION OF FLAT-HEAD SCREWS}

\section{DESCRIPTION OF TEST}

\section{Test Apparatus}

All tests were performed on an existing small torque test fixture, shown in Figure 1 . The torque-application portion of the fixture consists of a shaft that is supported through two pairs of pillow blocks, as shown. Torque in the shaft is measured by a small strain-gage-style torque cell located between the pairs of pillow blocks. The excitation signal for the load cell is provided by the instrument located to the right of the photograph. This instrument also provides output indication for the load cell over a range of 0 to 200 inch pounds. The meter on the instrument is configured so that the maximum indication reached is held by the pointer until reset by the operator.

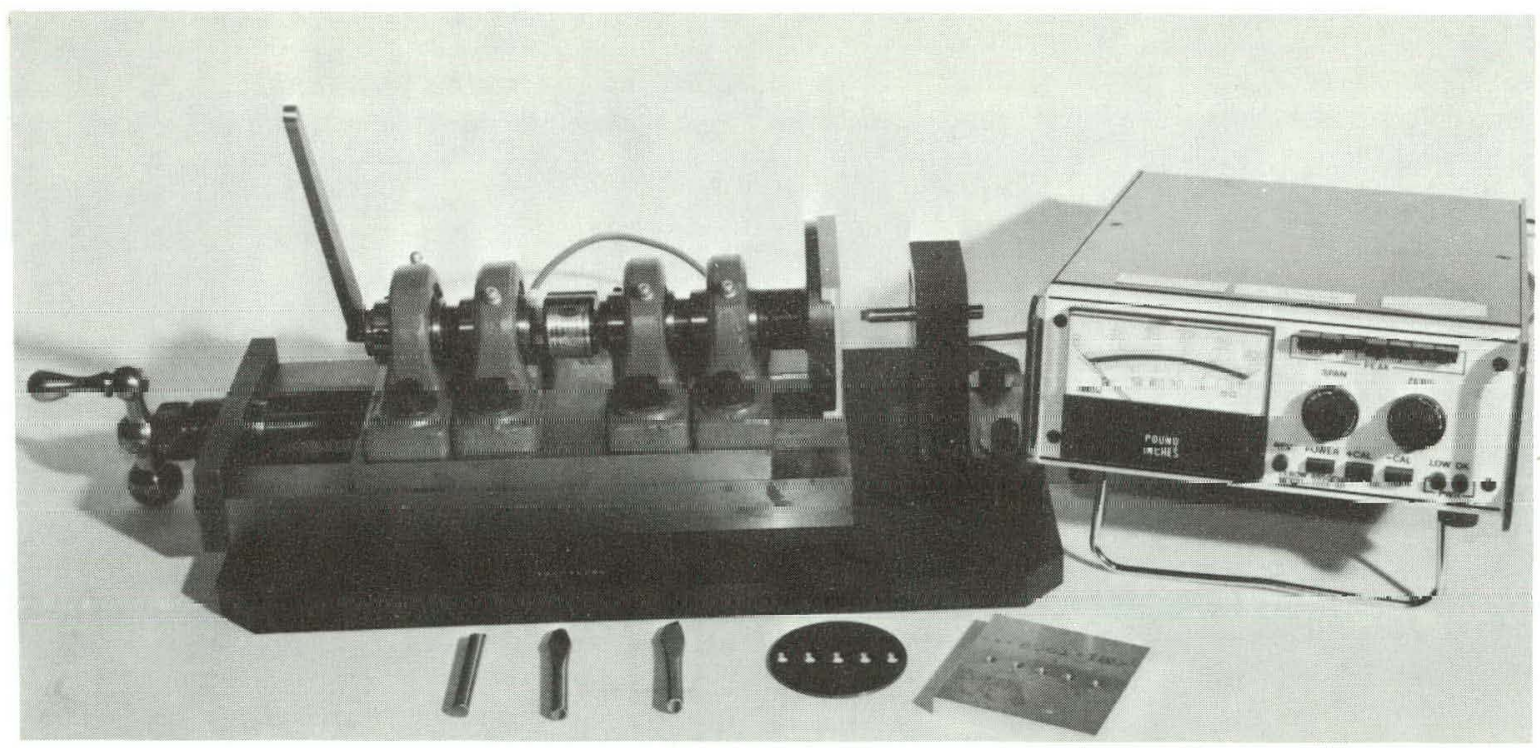

Figure 1. OVERALL VIEW OF THE SMALL TORQUE TEST FIXTURE.

183834 handle seen attached to the left end of the shaft, immediately adjacent to the pillow block. The shaft-and-pillow block assembly is attached to a machine slide which may be moved right or left through the screw handle shown at the lower left.

In the foreground of Figure 1 are the screwdriver shafts and test plates. These items are seen more clearly in Figure 2. Detailed drawings of all these parts are given in the Appendix.

The test plates were machined to the design seen in Figure 2 to duplicate, as near as possible, the actual operating conditions of the screw. The lower tapped plate was made of 


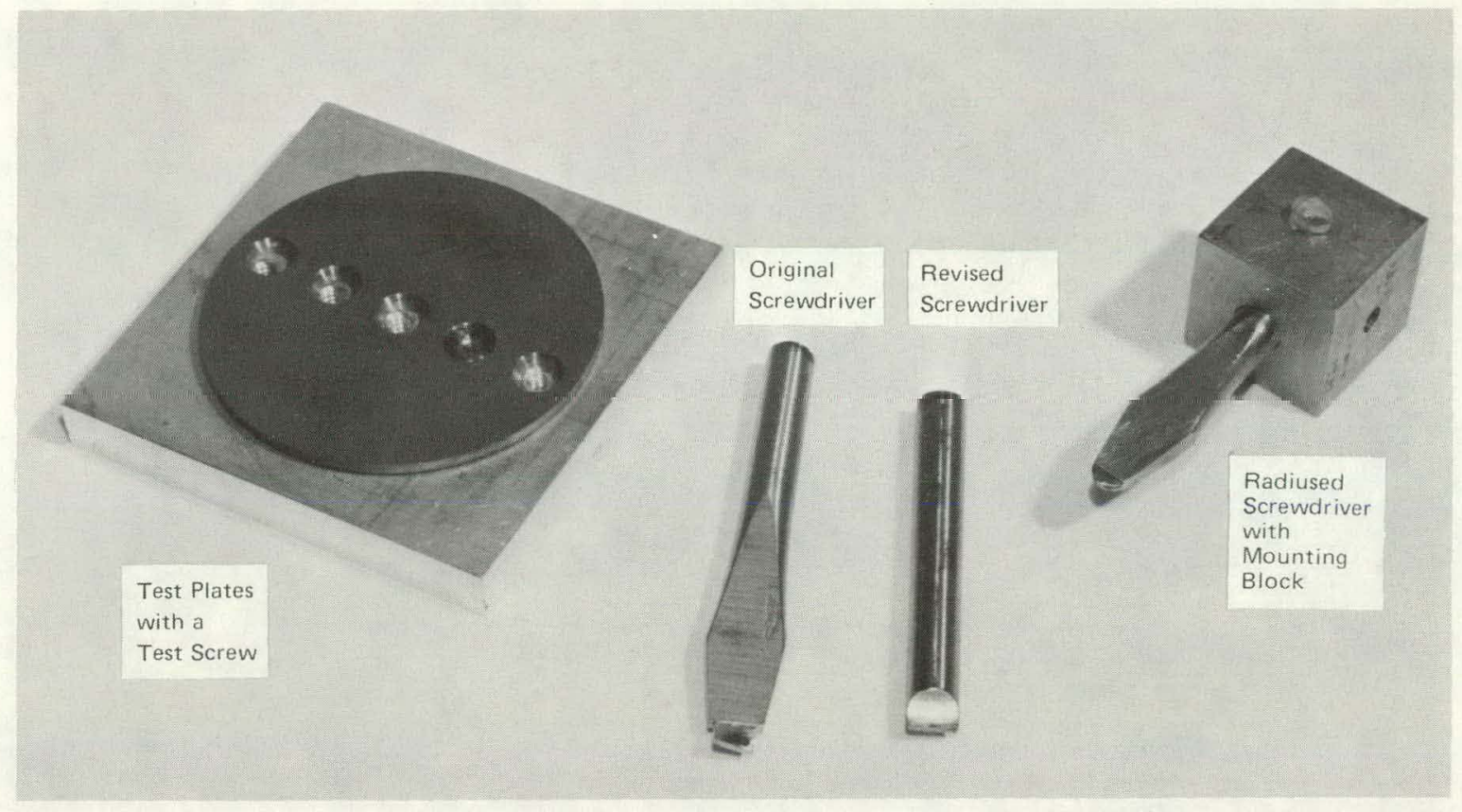

Figure 2. TEST PLATES AND SCREWDRIVERS.

183835

Type 6061-T6 aluminum plate and the plate with countersunk holes was made of depleted uranium. Five holes were drilled in each aluminum plate, and enough plates were machined so that each test was performed in an unused tapped hole. The same uranium plate was used for all tests.

Two straight (normal) screwdrivers were used (Figure 2) due to the failure of the first design on the first test attempt. The revised design (Figure 2) and Figure A-5 (Appendix) was machined from the shaft of the screwdriver used to make the initial design, and it was used for all tests on the normal screw heads. The radiused-end screwdriver was also slightly modified by the addition of a radius to the shoulder fillet, also shown in detail in Figure A-7, Appendix.

Detailed in Figure 3 is the configuration of the test fixture used to test all the screws. Also shown is the radiused-end screwdriver shaft mounted in the square block and the plate assembly with a screw in place. The plate assembly is held in place by six set screws, three of which can be seen in the figure. These screws were not tightened until the operator was sure the screwdriver shaft and screw were properly aligned. As can be noted from the photograph, the plate could be moved so as to align any one of the five holes with the screwdriver shaft.

Not mentioned up to this point is the fact that use of this fixture required that the usual role of screw and tapped hole is reversed. That is, the screw was held stationary and the plate turned, but it was felt that this was of no consequence to the end test results. 


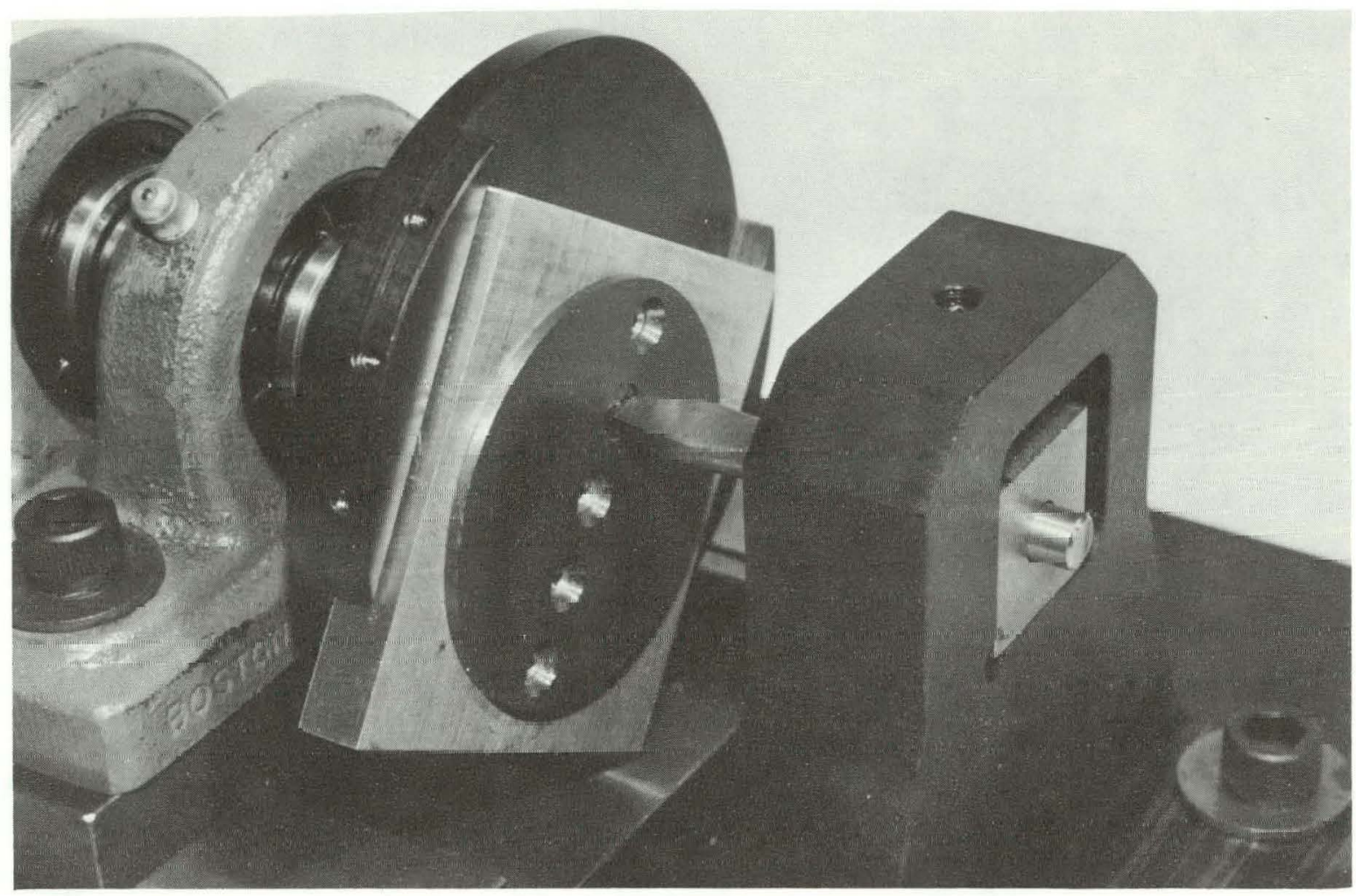

Figure 3. CLOSEUP VIEW OF THE TEST SETUP.

183836

\section{Test Procedure}

Alignment of the screwdriver shaft and centerline of the torque shaft was checked prior to testing and the end block shimmed so that the two shafts were aligned to within \pm 20 mils. The procedure used to perform the torque test was as follows:

1. The proper screwdriver was chosen and mounted.

2. The screw was threaded into the plate and tightened by hand, then the plate was installed on the machine.

3. The slide was moved up until the screwdriver engaged the screw slot.

4. Slight hand torque was used to snug the screw into the plate.

5. Slight end loading was placed on the screw and screwdriver through the machine slide.

6. An initial torque of 20 inch pounds was placed on the screw, then the screw was removed and examined for failure, if any. 
7. Finally, the screw was reinstalled and tested to failure, then the maximum load and failure mode were recorded.

\section{Test Results}

All screws were machined from two 1/2-inch-diameter U-6 Nb rods. In addition to five screws obtained from each rod, one threaded-end tensile specimen was also machined. The latter was a standard one-inch-gage length, 0.250-inch-diameter ASTM specimen. Test results from these specimens are listed in Table 1.
Table 1

TENSILE SPECIMEN TEST RESULTS

\begin{tabular}{lcccc}
\hline $\begin{array}{c}\text { Rod Process } \\
\text { Number(1) }\end{array}$ & $\begin{array}{c}\text { Tensile } \\
\text { Strength } \\
\text { (ksi) }\end{array}$ & $\begin{array}{c}\text { Yield } \\
\text { Strength(2) } \\
\text { (ksi) }\end{array}$ & $\begin{array}{c}\text { Percent } \\
\text { Elongation (3) }\end{array}$ & $\begin{array}{c}\text { Reduction } \\
\text { in Area } \\
\text { (\%) }\end{array}$ \\
\hline $3693-65-8191(4)$ & 134.9 & 66.7 & 24.0 & 24.2 \\
$3693-65-8188$ (5) & 119.4 & 63.7 & 31.0 & 54.4 \\
\hline
\end{tabular}

(1) Reference Lab Codes S-78-1985 and -2050.

(2) At $0.2 \%$ offset.

(3) In 1 inch.

(4) Specimen 3693-66-8197.

(5) Specimen 3693-66-8208.

Notable in this table is the marked difference between the two rods in terms of their strengths and ductility, the first being of higher strength and lower ductility than the second. Unfortunately, the rod length did not allow any more specimens to be machined for a better analysis. However, these data should have been representative of the stock which will be used for future screw fabrication.

Presented in Table 2 are the torque test results of the tests performed on the normal slotted screws.

Table 3 gives similar results for the radiused-bottom slotted screws.

$3693-65-8188$

Table 2

TORQUE TEST RESULTS FOR THE NORMAL SLOTTED SCREW

\begin{tabular}{rrr}
\hline $\begin{array}{l}\text { Rod Process } \\
\text { Number (1) }\end{array}$ & $\begin{array}{c}\text { Specimen } \\
\text { Process } \\
\text { Number }\end{array}$ & $\begin{array}{c}\text { Failure Torque (2) } \\
\text { (in lbs) }\end{array}$ \\
\hline $3693-65-8191$ & $3693-68-8203$ & 80 \\
-8204 & 89 \\
-8205 & 89 \\
8206 & 89 \\
-8207 & 90 \\
$3693-65-8188$ & Average & $87.4, s=4.2$ \\
& & \\
& $3693-68-8214$ & 93 \\
-8215 & 90 \\
-8216 & 106 \\
& -8217 & 84 \\
& -8218 & 80 \\
Average for All 10 Specimens & $89.0, \mathrm{~s}=7.4$ \\
\hline
\end{tabular}

(1) Reference Lab Codes S-78-2330 and -2329.

(2) Failure mode in each case was at the base of the head.

Photographs of typical modes of failure are provided in Figures 4 and 5 . Note that all of the normal slotted screws failed in a tensile mode at the base of the head in the area of a thread relief. Six of the ten radiused-slot screws failed when the screwdriver shaft rotated out of the slot, tearing out the slot. An attempt was made to place more end loading on the screwdriver shaft through use of the slide screw, but this attempt was not successful in preventing this sort of failure. The other four radiused-slot screws failed in a manner 
similar to that of the normal slotted screws. The light-colored traces on the screws are undoubtedly due to rubbing contact with the aluminum plate.

\section{CONCLUSIONS AND RECOMMENDATIONS}

From the data presented in Tables 2 and 3 , it must be concluded that either of the two screw-head styles will meet the requirement of a 12-inch-pound installation torque and a 20-inch-pound proof torque with a comfortable safety margin. This conclusion may be reached in spite of the variability in
Table 3

TORQUE TEST RESULTS FOR THE RADIUSED SLOT SCREWS

\begin{tabular}{rrrl}
\hline $\begin{array}{c}\text { Rod Process } \\
\text { Number (1) }\end{array}$ & $\begin{array}{c}\text { Specimen } \\
\text { Process } \\
\text { Number }\end{array}$ & $\begin{array}{c}\text { Failure Torque } \\
\text { (in Ibs) }\end{array}$ & Failure Mode \\
\hline $3693-65-8191$ & $3693-67-8198$ & 84 & Base of Head \\
& -8199 & 88 & Base of Head \\
Base of Head \\
& -8200 & 96 & Base of Head \\
& -8201 & 92 & Head Slot Stripped \\
& -8202 & 102 & \\
Average & $92.4, \mathrm{~s}=7.0$ & \\
& & & Head Slot Stripped \\
$3693-65-8188$ & $3693-67-8209$ & 72 & Head Slot Stripped \\
& -8210 & 78 & Head Slot Stripped \\
& -8211 & 71 & Head Slot Stripped \\
& -8212 & 66 & \\
& -8213 & 66 & \\
Average of 10 Specimens & $81.5, \mathrm{~s}=12.8$ & \\
\hline
\end{tabular}

(1) Reference Lab Codes S-78-2353 and -2354.

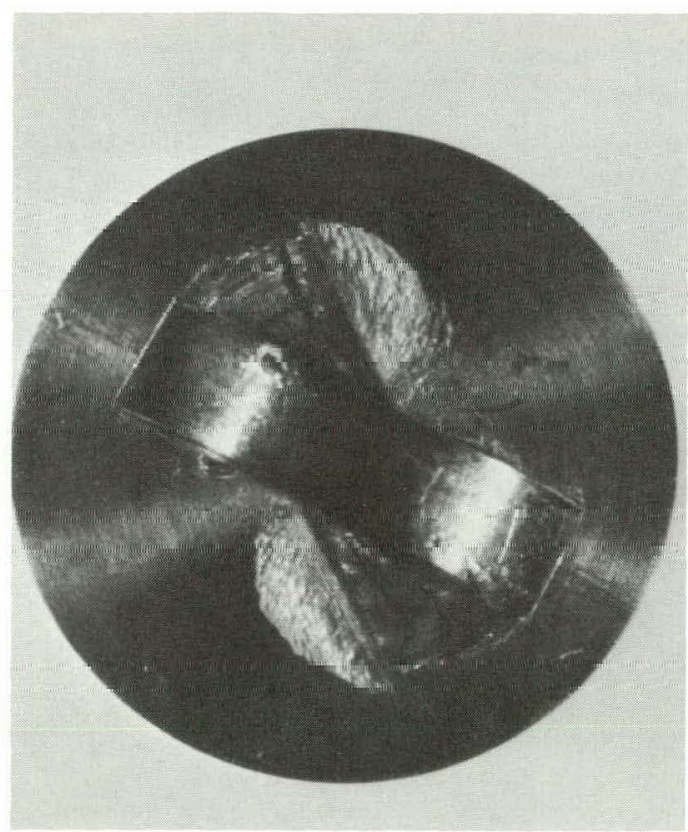

(a) Top View.

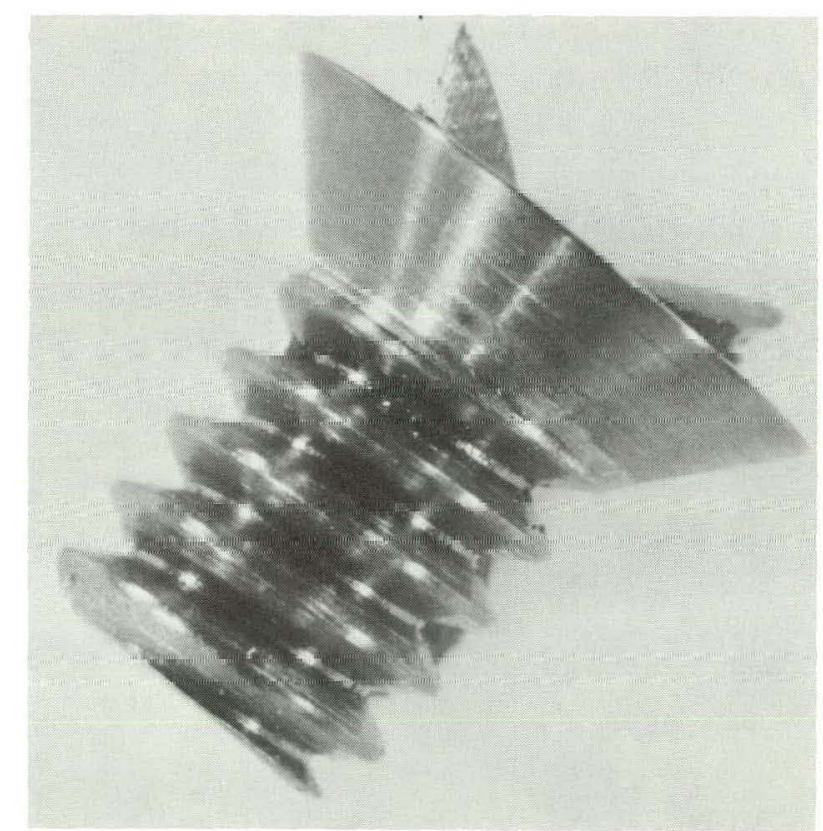

(b) Side View.

183837

Figure 4. VIEWS OF A RADIUSED-BOTTOM, SLOTTED SCREW.

mechanical-property test results, as presented in Table 1, for this variability seems to have had little effect on the test results. The only group for which this wide divergence is a 


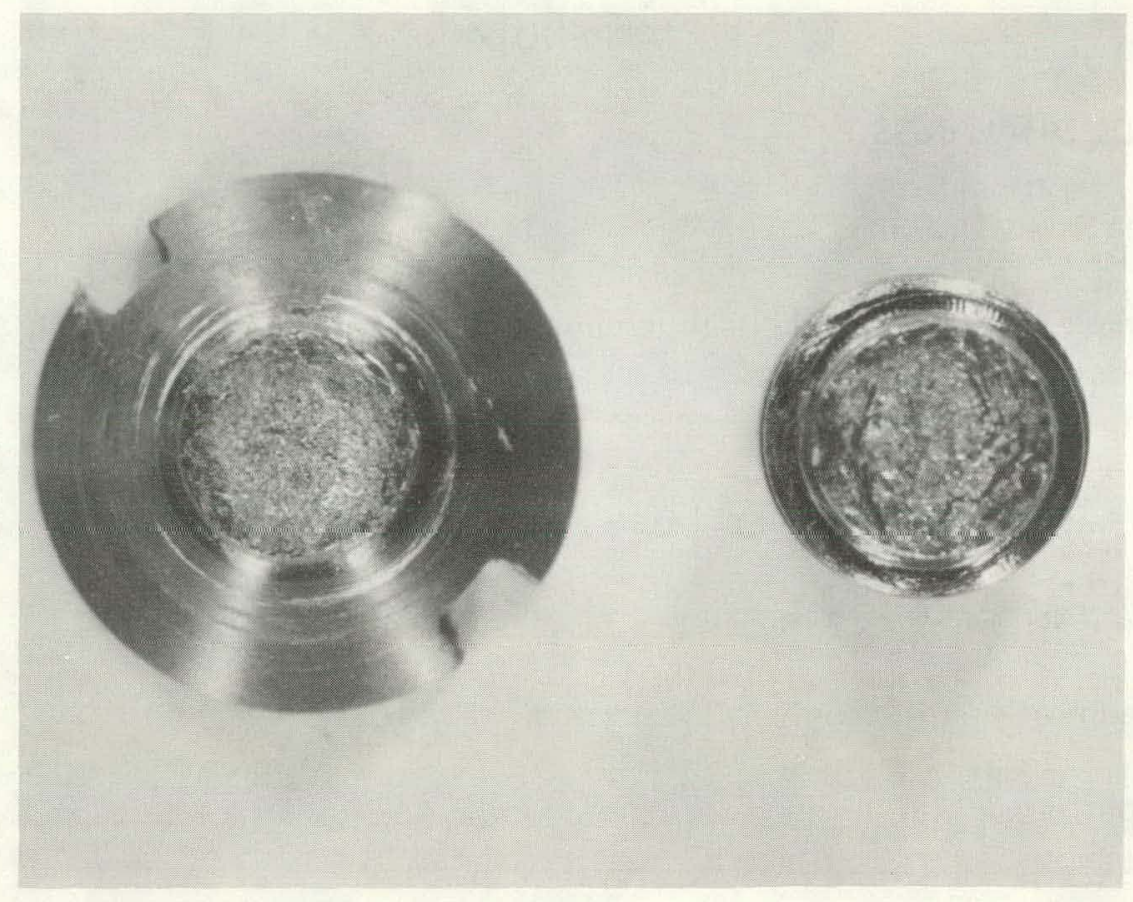

(a) End Views.

183840

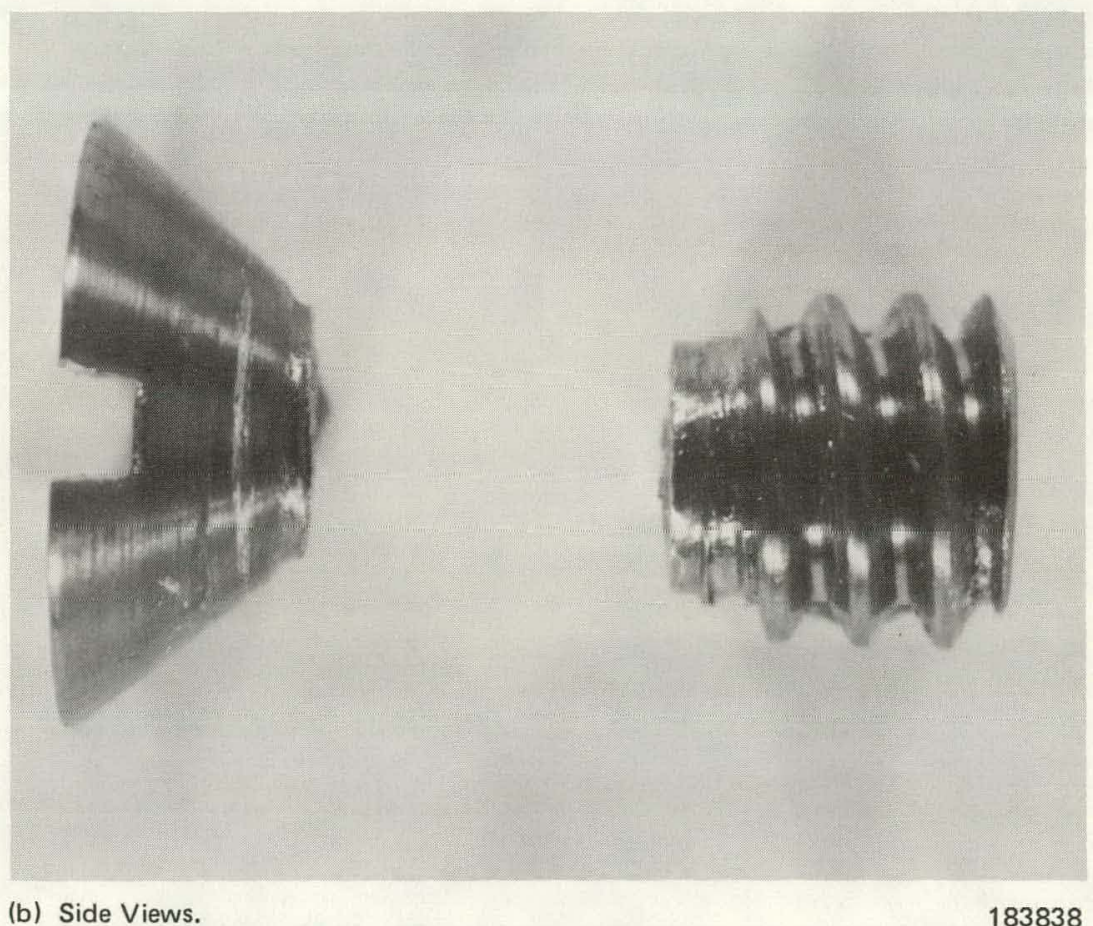

Figure 5. VIEWS OF A NORMAL SLOTTED SCREW.

questionable effect is for the radiused-bottom slotted screws that failed by stripping out the head. There is reason to believe that these results would have been higher and perhaps the failure mode different if more end load could have been placed on the screwdriver shaft. 


\section{APPENDIX}

\section{APPLICABLE DRAWINGS}

\section{Notes for the Screw Drawings}

The following information should be noted in connection with Figures A-1 and A-2.

1. Unless otherwise specified, all dimensions are in millimeters.

2. Surface texture is in micrometers; 1.6 all over except threads and recess.

3. Break sharp edges at 0.25 max radius or chamfer.

4. Feather edge of first thread must be removed.

5. Thread may break into the angle of the head up to one full turn, maximum. 


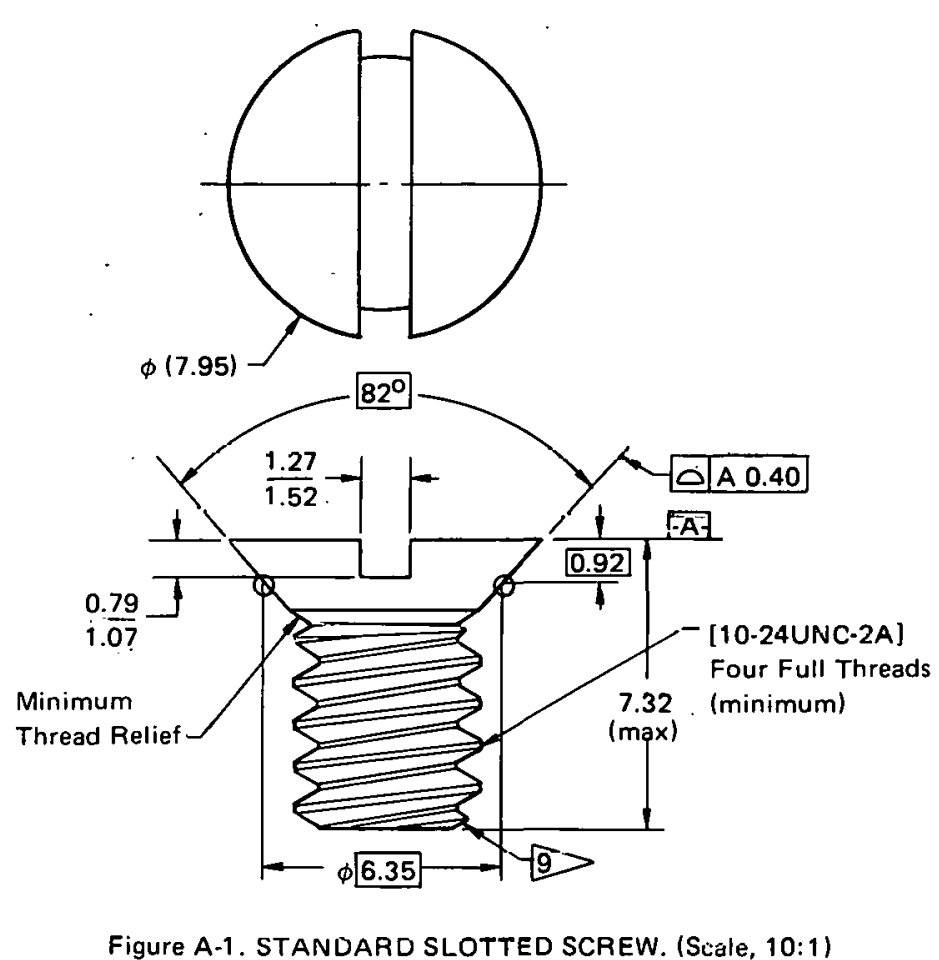

Figure A-1. STANDARD SLOTTED SCREW. (Scale, 10:1)

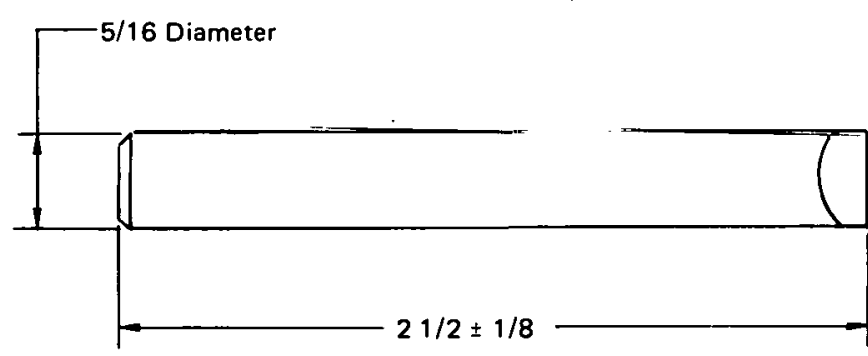

$H$
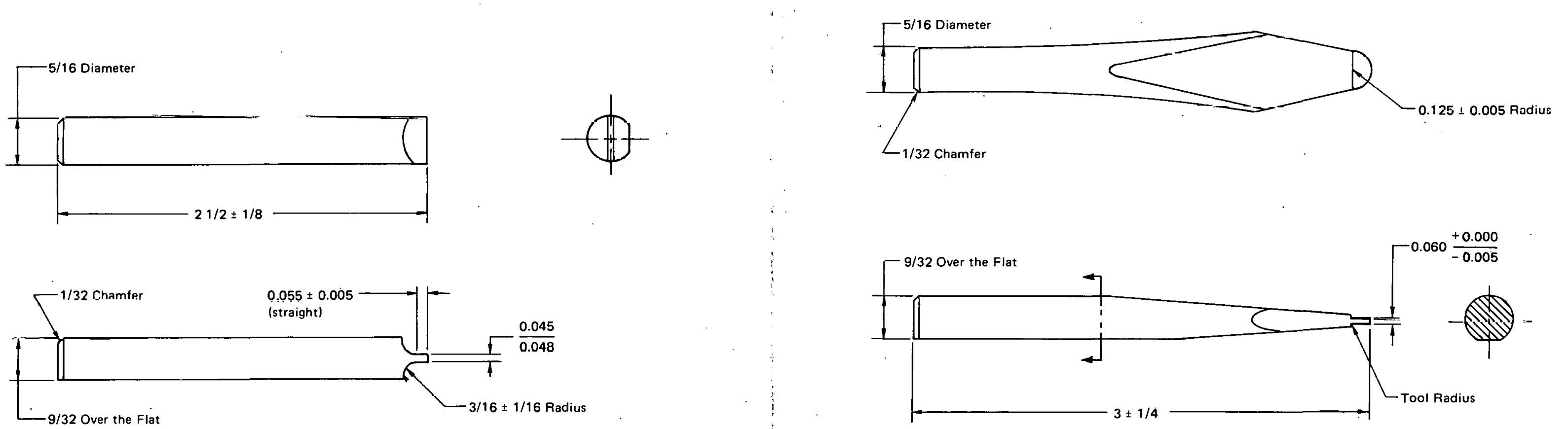

Figure A-5. STRAIGHT SCREWDRIVER-REVISED DESIGN. ISCale, 2:11)

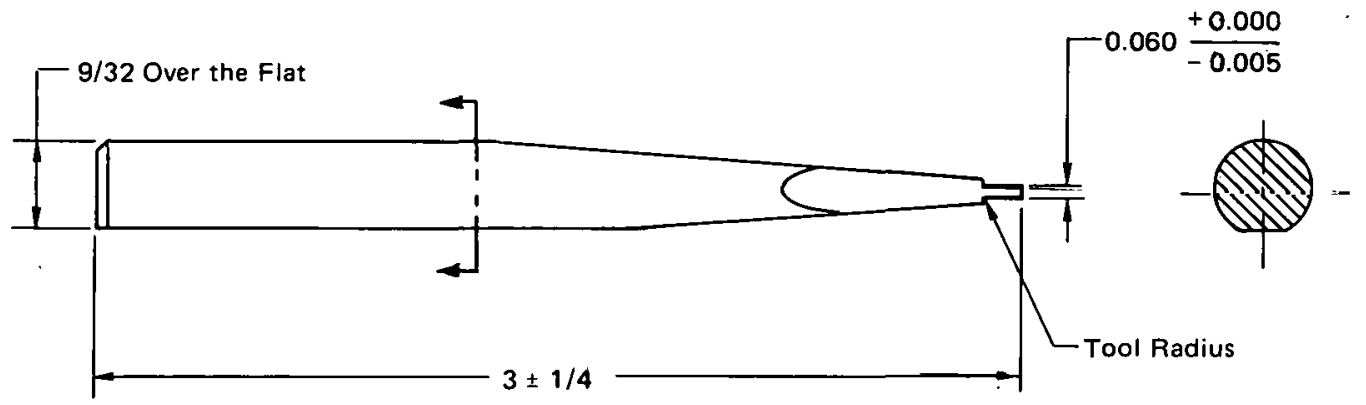

Figurc A6. RADIUSED SCREWDrivER-ORIGINAL UESIIGN. IScale, 2:11
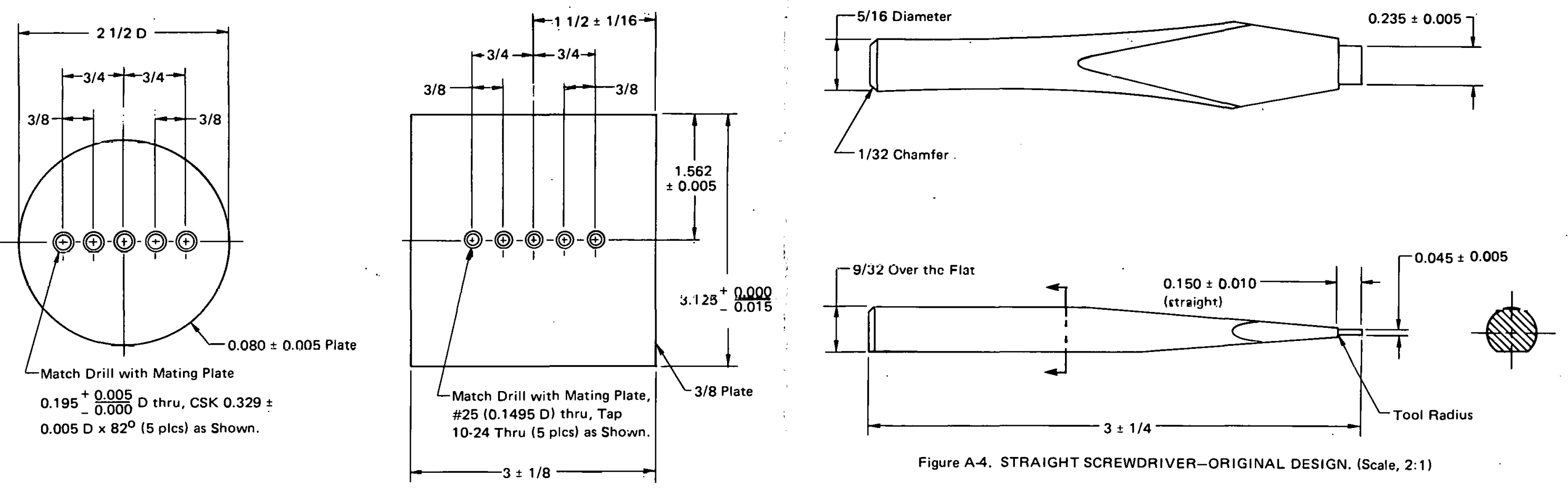

Figure A-3. DIMENSIONS OF THE ADAPTER AND THREADED TEST PLATES. FFull Scale
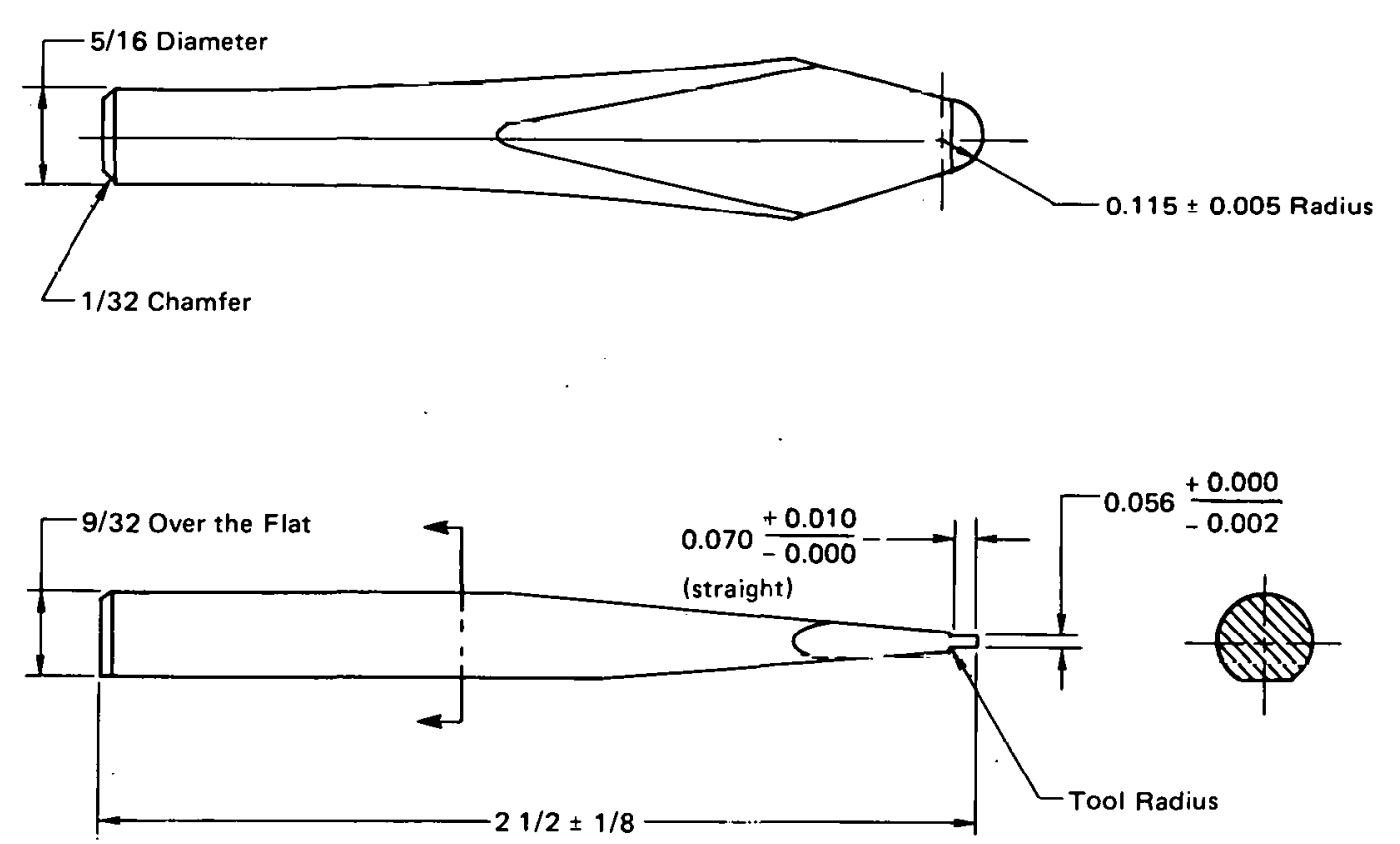

Figure A-7.7. RADIUSED SCREWDRIVER-REVISED DESIGN. (ICale, 2:1) 


\section{Distribution}

Department of Energy - Oak Ridge

Hickman, H. D.

Leed, R. E.

Zachry, D. S., Jr

Oak Ridge Gaseous Diffusion Plant

Frazier, J. L.

Stief, S. S:

Vornehm, R. G.

Wilcox, W. J., Jr

Oak Ridge National Laboratory

Brinkman, C. R.

\section{Oak Ridge Y-12 Plant}

Alvey, H. E.

Bagwell, B. L.

Bailey, H. L.

Bernander. N. K.

Bright, G. R.

Briscoe, O.W.

Bryant, D. P.

Burditt, R. B.

Cuddy, L. M.

Dodson, W. H./Googin, J. M.

Foulk, D. L.

Fraser, R. .J.

Gritzner, V. B.

Hunter, A. H.

Jackson, V.C.

Johnson, W. B. (5)

Jones, F. W.

Kahl, K. G.

Keith, A.

Kite, H. T.

Long, P. J.

Mason, D. L./Schneider, P. G./Oakes, R. E., Jr

Mills, J. E.

Mills, J. M., Jr

Perry, A. E.

Phillips, L. R.

Poore, M. W.

Reeves, C. A., Jr (5)
Schede, R.W.

Smith, H. F., Jr

Smith, R. D.

Stoner, H. H.

Tilson, F. V.

Wallace, S. A.

White, J. C.

Y-12 Central Files (master copy)

$Y-12$ Central Files (route copy)

$Y-12$ Central Files $(Y-12 R C)$

$Y-12$ Central Files (5)

Paducah Gaseous Diffusion Plant

Bewley, H. D.

In addition, this report is distributed in accordance with the Category UC-38, Engineering and Equipment, as given in the USERDA Standard Distribution Lists for Unclassified Scientific and Technical Reports, TID-4500. 